\title{
Late Holocene sea-level rise in Tampa Bay: Integrated reconstruction using biomarkers, pollen, organic-walled dinoflagellate cysts, and diatoms
}

\author{
E.E. van Soelen ${ }^{\text {a, }}$, E.I. Lammertsma ${ }^{\text {b }}$, H. Cremer $^{\text {c }}$, T.H. Donders ${ }^{c}$, F. Sangiorgi ${ }^{\text {b }}$, G.R. Brooks ${ }^{\text {d }}$, \\ R.A. Larson ${ }^{\mathrm{d}}$, J.S. Sinninghe Damsté ${ }^{\mathrm{a}, \mathrm{e}}$, F. Wagner-Cremer ${ }^{\mathrm{b}}$, G.J. Reichart ${ }^{\mathrm{a}, \mathrm{f}}$ \\ ${ }^{a}$ Department of Earth Sciences - Geochemistry, Faculty of Geosciences, Utrecht University, Budapestlaan 4, 3584 CD Utrecht, The Netherlands \\ ${ }^{\mathrm{b}}$ Palaeoecology, Institute of Environmental Biology, Science Faculty, Utrecht University, Laboratory of Palaeobotany and Palynology, Budapestlaan 4, \\ 3584 CD Utrecht, The Netherlands \\ ${ }^{\mathrm{c}}$ Geological Survey of The Netherlands, PO Box 80015, 3508 TA Utrecht, The Netherlands \\ ${ }^{\mathrm{d}}$ Department of Marine Science, Eckerd College, 4200, 54th Avenue South, St. Petersburg, FL, USA \\ e Department of Marine Organic Biogeochemistry, NIOZ Royal Netherlands Institute for Sea Research, PO Box 59, 1790 AB Den Burg, The Netherlands \\ ${ }^{\mathrm{f}}$ Alfred Wegener Institut for Polar and Marine Research, Am Handelshafen 12, D-27570 Bremerhaven, Germany
}

\section{A R T I C L E I N F O}

\section{Article history:}

Received 18 June 2009

Accepted 9 November 2009

Available online 14 November 2009

\section{Keywords:}

Palaeoenvironments

Holocene

Estuaries

Sea-level changes

Florida

\begin{abstract}
A B S T R A C T
A suite of organic geochemical, micropaleontological and palynological proxies was applied to sediments from Southwest Florida, to study the Holocene environmental changes associated with sea-level rise. Sediments were recovered from Hillsborough Bay, part of Tampa Bay, and studied using biomarkers, pollen, organic-walled dinoflagellate cysts and diatoms. Analyses show that the site flooded around $7.5 \mathrm{ka}$ as a consequence of Holocene transgression, progressively turning a fresh/brackish marl-marsh into a shallow, restricted marine environment. Immediately after the marine transgression started, limited water circulation and high amounts of runoff caused stratification of the water column. A shift in dinocysts and diatom assemblages to more marine species, increasing concentrations of marine biomarkers and a shift in the Diol Index indicate increasing salinity between 7.5 ka and the present, which is likely a consequence of progressing sea-level rise. Reconstructed sea surface temperatures for the past 4 kyrs are between 25 and $26^{\circ} \mathrm{C}$, and indicate stable temperatures during the Late Holocene. A sharp increase in sedimentation rate in the top $\sim 50 \mathrm{~cm}$ of the core is attributed to human impact. The results are in agreement with parallel studies from the area, but this study further refines the environmental reconstructions having the advantage of simultaneously investigating changes in the terrestrial and marine environment.
\end{abstract}

(c) 2009 Elsevier Ltd. All rights reserved.

\section{Introduction}

Holocene sea-level rise shaped the low lying Gulf Coast of Florida into its present day appearance. Sea-level studies for this region suggest a transgression over the past $10 \mathrm{kyrs}$, although there is a contrast between studies showing decelerating rates over the past 5000 years (Scholl et al., 1969; Törnqvist et al., 2004) and studies showing a Mid or Late Holocene sea-level highstand (Goodbred et al., 1998; Blum et al., 2001; Törnqvist et al., 2004). Detailed studies of the impact of Holocene sea-level rise can be used for improving our understanding of the environmental implications associated with the modern and forecasted sea-level

\footnotetext{
* Corresponding author. Present address: P.O. Box 80.021, 3508 TA Utrecht, The Netherlands.

E-mail address: e.vansoelen@geo.uu.nl (E.E. van Soelen).
}

rise. Multi-proxy studies are a valuable tool for paleo-environmental reconstructions especially when they combine marine and terrestrial environmental information.

Pollen provides a valuable proxy for environmental reconstructions because of its good preservation, abundant presence in most terrestrial and marine sediments and its sensitivity to changes in southwest Florida's hydrological cycle (Donders et al., 2005; Willard et al., 2007). Pollen abundances reflect regional vegetation development and, in marine records, also record variations in runoff rates. Nearby coastal vegetation can further influence the signal (Donders et al., 2008). Facies changes as a result of sea-level fluctuations can also affect the pollen signal by altering the depositional setting, as is evident in the late-Glacial from the southwestern Florida Tampa Bay record (Willard et al., 2007).

Diatoms and dinoflagellates thrive in offshore waters and their remains (e.g. diatom frustules and organic-walled dinoflagellate cysts, or dinocysts) have been found in surface sediments of Florida 
shallow marine environments such as Rookery Bay (Cremer et al., 2007). Relative species distributions of these groups can be used to reconstruct amongst others: sea surface salinity, stratification and productivity (Laws, 1988; Marret and Zonneveld, 2003; Sangiorgi et al., 2006; Van der Meer et al., 2008).

Another valuable proxy for environmental reconstructions is biomarkers. These geochemical fossils are specific compounds, mostly lipids, which can be linked to their organic precursors and can preserve over long geological time scales (Killops and Killops, 2005). Biomarkers derive from plants and trees but also from microorganisms like dinoflagellates, diatoms, coccolithophore, and are therefore ideally suited to link the terrestrial and marine environment. Terrestrial biomarkers can provide information on changes in hydrology like increased runoff. Marine biomarkers are often used for the reconstruction of marine variables such as sea surface temperature (Prahl and Wakeham, 1987), salinity (Versteegh et al., 1997) and productivity (Sachs and Anderson, 2005). Hence, combining biomarkers with terrestrial and marine microfossil records makes the environmental reconstructions more robust.

One of the largest estuaries in southwest Florida is Tampa Bay, which consists of interconnected bays and lagoons with shallow water depth. In 2004 a $\sim 5 \mathrm{~m}$ continuous Holocene record was recovered from Hillsborough Bay, part of Tampa Bay (Cronin et al., 2007). A shift in sediment and microfossil content around 7 ka was interpreted as a transition from a lacustrine to an estuarine environment, as a consequence of post-glacial sea-level rise (Cronin et al., 2007). The rise in sea-level is estimated to be about $7.5-8 \mathrm{~m}$ over the last $\sim 7$ kyrs at this site (Cronin et al., 2007). Here we build upon the initial study by Cronin et al. (2007) applying a suite of organic geochemical and micropaleontological proxies to gain detailed environmental information from the terrestrial and the marine environment during Holocene sea-level rise.

\section{Material and methods}

\subsection{Material}

Hillsborough Bay core TB-04-VC-77 (Fig. 1) was collected in summer 2004, by the U.S. Geological Survey in cooperation with Eckerd College and the University of South Florida, with a vibracorer deployed from the R/V Gilbert. The core comprises $511 \mathrm{~cm}$ of sediments collected at a water depth of $\sim 4 \mathrm{~m}$ in a $6 \mathrm{~m}$ long by $7.6 \mathrm{~cm}$ wide aluminium barrel. Based on the down core changes in sediment colour ten samples were selected and freezedried (Fig. 1). These samples were split for the different analytical techniques, allowing direct comparison of proxies and results. Depths are relative to the core top and reported in $\mathrm{cm}$ below sea floor (cmbsf).

\subsection{Age model}

The age model is constructed using two linearly interpolated radiocarbon dates (Cronin et al., 2007) and pollen biostratigraphical ages (Fig. 1). Radiocarbon ages are based on Polygonum-seeds (depth: $4.28 \mathrm{~m},{ }^{14} \mathrm{C}$ age: $8223 \mathrm{yr} \mathrm{BP} \pm 50 \mathrm{yr}$ ), and Mulinia sp. shells (depth: $3.1-3.15 \mathrm{~m},{ }^{14} \mathrm{C}$ age: $5441 \mathrm{yr} \mathrm{BP} \pm 40 \mathrm{yr}$ ) and were calibrated using atmospheric and marine corrections (CALIB 5.0.2, http://calib. qub.ac.uk/calib/) (Cronin et al., 2007).

Casuarina (Australian pine) has its first occurrence between samples 93 and $39 \mathrm{cmbsf}$. It is an exotic plant introduced to the Florida peninsula around $1900 \mathrm{AD}$ (Alexander and Crook, 1974), corresponding with a pollen-age of $\sim 50 \mathrm{yr}$ BP (i.e. before 1950). A strong expansion of Pinus between sample depths 352 and $329 \mathrm{cmbsf}$ is dated between 7.2 and 4.4 ka based on regional correlation (Watts, $1969,1971,1975,1980$, Watts and Hansen, 1994). According to the age model, the sediments represent approximately the last $\sim 10 \mathrm{kyr}$, presuming deposition rates of $0.04 \mathrm{~cm} / \mathrm{yr}$ to $\sim 0.3 \mathrm{~cm} / \mathrm{yr}$ based on this core and previous studies (Brooks, in press).

\subsection{Biomarkers}

Extracts were obtained from ca 1.5-6.5 g of freeze-dried and powdered sediments, using an ultrasonic homogenizer (Branson sonifier 250 Analog) and a solvent mixture of dichloromethane (DCM) and methanol $(\mathrm{MeOH})(2: 1 \mathrm{v} / \mathrm{v})$. Samples were ultrasonically stirred 5 times for 3 min. Resulting extracts were combined and rotary-evaporated under near vacuum to remove solvents. Extracts were treated with activated copper to remove elemental sulfur. Traces of water were removed with sodium sulfate.

Quantification of compounds was performed on gas chromatograms of total lipid fractions (TLFs). Extracts were treated with diazomethane to convert fatty acids into methyl esters and with N.O-Bis(trimethylsilyl)trifluoroacetamide (BSTFA) to convert alcohols into trimethylsilyl (TMS) ethers.

Extracts were separated into three fractions of different polarity to enable identification of compounds with relative low concentrations. An aliquot of the total extracts ( $\sim 80 \%)$ was separated over a column with activated aluminum oxide using solvent mixtures hexane:DCM (9:1 v/v), DCM and DCM:MeOH (1:1 v/v), resulting in, respectively, a fraction containing alkanes, alkenes and aromatics, a fraction containing aldehydes and ketones, and a fraction containing polar compounds.

Gas chromatography (GC) was performed using an HP Gas Chromatograph fitted with a CP-Sil 5CB fused silica capillary column (30 $\mathrm{m} \times 0.32 \mathrm{~mm}$ i.d.) and a flame ionization detector (FID). A flame photometric detector (FPD) was used to check for elemental and bound sulfur. Samples were injected on-column, with helium as carrier gas set at constant pressure (100 KPa). The oven was programmed starting at $70^{\circ} \mathrm{C}$, heating by $20^{\circ} \mathrm{C} / \mathrm{min}$ up to $130{ }^{\circ} \mathrm{C}$, by $4{ }^{\circ} \mathrm{C} / \mathrm{min}$ up to $320^{\circ} \mathrm{C}$ and then kept at this temperature for $20 \mathrm{~min}$. Mass spectrometry (GCMS) was performed using a ThermoFinnigan Trace GCMS with the same type of column and oven program as used for the GC. Compounds were identified using retention times and mass spectra. Quantification of compounds was performed by peak area integration in FID chromatograms relative to a standard (squalane) which was co-injected with TLF.

Total organic carbon (TOC) content of sediment samples was determined with a Fison Instrument NA 1500 NCS analyzer, on samples treated with $\mathrm{HCl}$ to remove inorganic carbon. The alkenone unsaturation index $\left(\mathrm{U}_{37}^{K^{\prime}}\right)$ was calculated, based on the relative abundances of $C_{37}$ alkenones with 2 or 3 double bonds (Prahl and Wakeham, 1987), which were present in the fraction containing aldehydes and ketones.

$\mathrm{U}_{37}^{K^{\prime}}=[\mathrm{C} 37: 2] /[\mathrm{C} 37: 2+\mathrm{C} 37: 3]$

Sea surface temperatures were calculated using the global calibration of Müller et al. (1998).

$\mathrm{U}_{37}^{K^{\prime}}=0.033^{*} \mathrm{~T}+0.069$

A diol index (DI) was calculated based on relative abundances of $C_{30^{-}}$and $C_{32^{-}}$1,15 diols (Versteegh et al., 1997), present in the TLF.

$$
\begin{aligned}
\text { Diol index }= & 100 *\left[C_{30} 1,15 \mathrm{diol}\right] /\left(\left[C_{32} 1,15 \mathrm{diol}\right]\right. \\
& \left.+\left[C_{30} 1,15 \mathrm{diol}\right]\right)
\end{aligned}
$$

\subsection{Palynology}

Sediments for palynological analysis were dried, weighed, and treated following standard methodology (Wood et al., 1996). Prior 


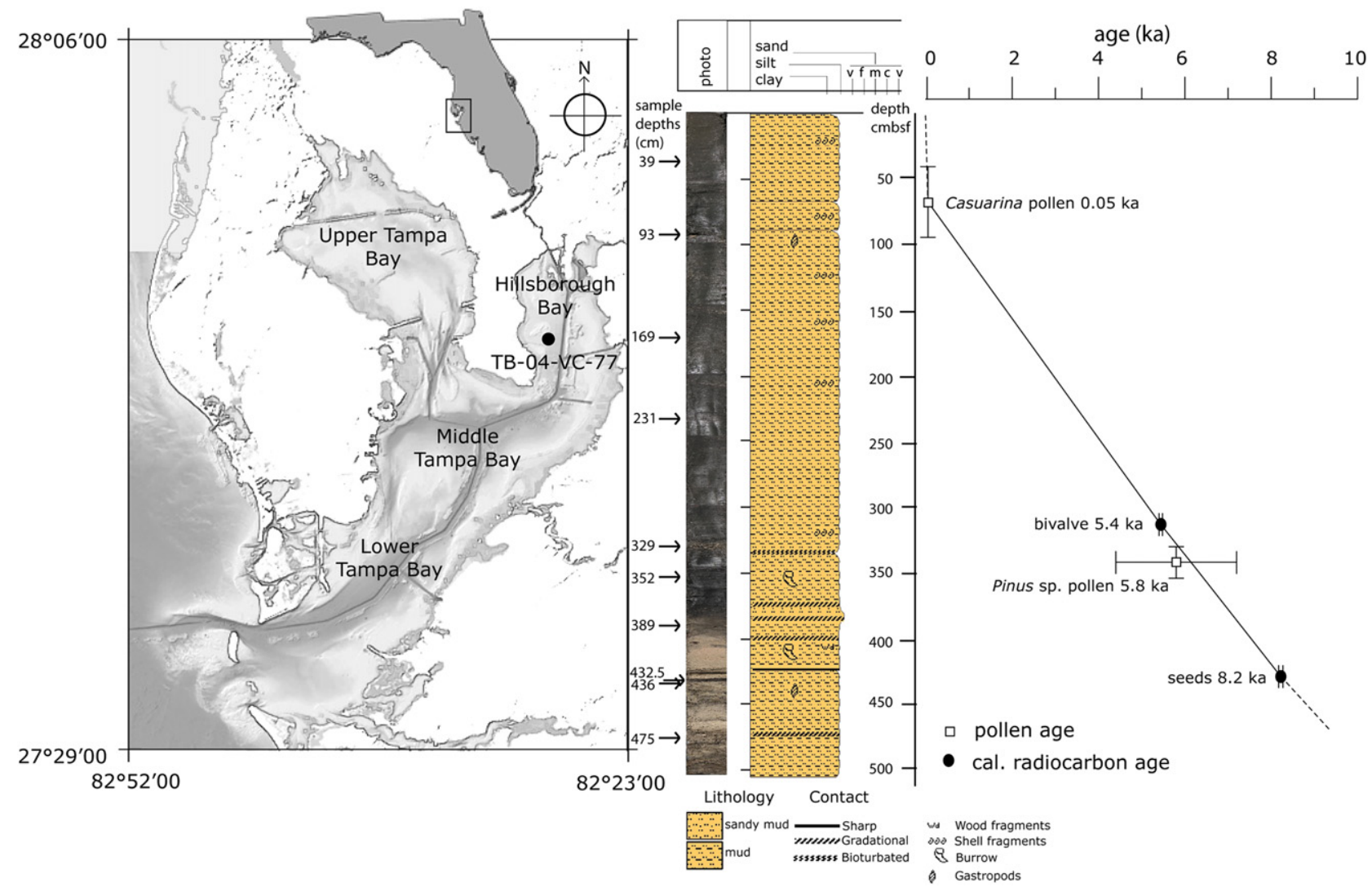

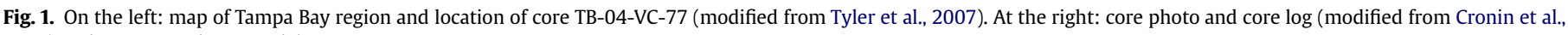
2007) and constructed age model.

to processing Lycopodium clavatum tablets with known amount of spores were added to the samples in order to be able to calculate concentration values. Treatment included the removal of carbonates with hydrogen chloride $(\mathrm{HCl})(30 \%)$, and silicates with hydrogen fluoride (HF) (40\%). Coarse and fine material was removed from the samples using sieves with a $250 \mu \mathrm{m}$ and $10 \mu \mathrm{m}$ mesh, respectively. The residues were mixed with glycerine and mounted on glass slides for analysis using a Leitz light microscope $(400 \times$ magnification). Pollen was identified following Willard et al. (2004). Identification of dinoflagellate cysts (dinocysts) was based on Rochon et al. (1999), Marret and Zonneveld (2003), Fensome and Williams (2004) and Cremer et al. (2007). The abundance of pollen and dinocysts is calculated relatively to the total sum of pollen and dinocysts, respectively. Identified plant and tree taxa are grouped into 'marsh' and 'upland' vegetation according to their highest abundance in these vegetation types (Myers and Ewel, 1990; Willard et al., 2001, Willard et al., 2006).

\subsection{Diatoms}

Diatom samples were treated with $\mathrm{HCl}$ and hydrogen peroxide $\left(\mathrm{H}_{2} \mathrm{O}_{2}\right)$ to dissolve carbonate and organic matter. Diatom slides were prepared using sedimentation trays (Battarbee, 1973), Naphrax ${ }^{\mathrm{TM}}$ was used to mount the cover slips on slides. Identification is based on floras published by Cremer et al. (2007), Hustedt (1930-1966, 1955) and Witkowski et al. (2000). In general, up to 200 diatom valves were counted on each slide. Groups of polyhalobous and mesohalobous diatoms were made, based on the salinity tolerance of each species (Simonsen, 1962; Laws, 1988).

\section{Results}

\subsection{Biomarkers}

Based on biomarker assemblages, the core can be divided into a lower section (below $\sim 400 \mathrm{cmbsf}$ ) of which an example of a TLF GC trace is presented in Fig. 2A, and an upper section (above $\sim 400 \mathrm{cmbsf}$ ) for which an example of a TLF GC trace is presented in Fig. 2B. Concentration profiles (in $\mu \mathrm{g} / \mathrm{g}$ TOC) of most abundant biomarkers and biomarkers which can be related to specific environmental conditions are presented in Fig. 3.

The steroid $\beta$-sitosterol is most abundant in the lower section and concentrations vary between 8 and $14 \mu \mathrm{g} / \mathrm{g}$ TOC. Taraxerol is also present in this lower section albeit in low amounts (up to $2 \mu \mathrm{g} / \mathrm{g}$ TOC). Between 432.5 and $352 \mathrm{cmbsf}$ there is a strong increase in concentrations of taraxerol, friedelanone, dinosterol and $C_{30}$ 1,15diol, all reaching maximum values at $352 \mathrm{cmbsf}$. Above this depth level, concentrations of these biomarkers generally decrease. In the sample at $329 \mathrm{cmbsf}$ concentrations are extremely low (between 3.5 and $5 \mu \mathrm{g} / \mathrm{g}$ TOC). The $\mathrm{C}_{36}$ alkenone has a similar concentration profile; however, it disappears from the record from $93 \mathrm{cmbsf}$ upward. Long-chain $C_{37}$ and $C_{38}$ alkenones were absent in the lower part of the core and first recognized at a depth of $\sim 329 \mathrm{cmbsf}$. Subsequently, concentrations first increase up to $169 \mathrm{cmbsf}$ and then decrease again. Tetrahymanol was only present in samples 389 and $352 \mathrm{cmbsf}$. Calculation of $\mathrm{U}_{37}^{K^{\prime}}$ resulted in values between 0.9 and 0.93 , corresponding to temperatures between 25 and $26.2^{\circ} \mathrm{C}$. The Diol Index is 28 at $389 \mathrm{cmbsf}$ and 25 at $352 \mathrm{cmbsf}$, increases up to 48 at 231 cmbsf and in the upper part increases to $>70$, with a maximum of 97 at 93 cmbsf. At sample depth $329 \mathrm{cmbsf}$, concentrations of $C_{30}$ and $C_{32}$ 1,15-diol were too low to be quantified, and the Diol Index could not be calculated for this depth. 


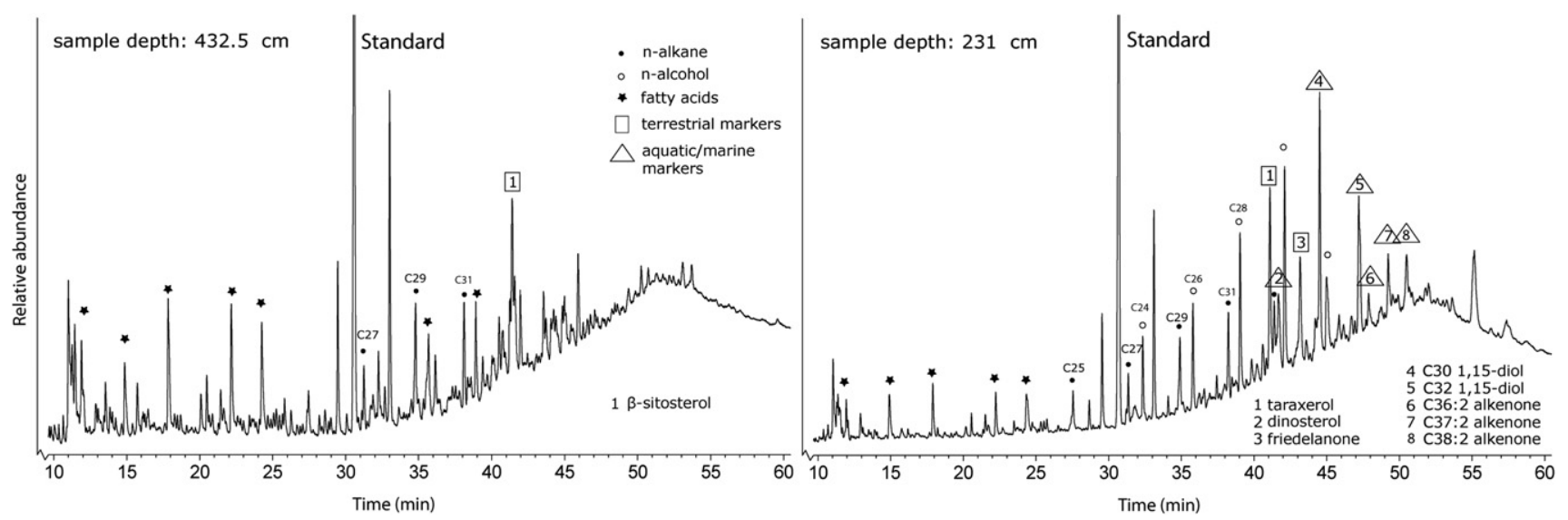

Fig. 2. Partial gas chromatograms (10-60 min) of total lipid fractions of samples $432.5 \mathrm{cmbsf}$ (left) and $231 \mathrm{cmbsf}$ (right).

\subsection{Pollen}

In general, the samples were rich in pollen and a large diversity of plant and tree taxa could be distinguished. Based on the overall changes the record can be subdivided into two distinct zones: TB-I and TB-II (Fig. 4).

Pollen zone TB-I. Amaranthaceae - Quercus zone (475$340 \mathrm{cmbsf}$ ). This zone is characterized by a variety of herbaceous taxa, of which Amaranthaceae is dominant with values up to $80 \%$ at $432.5 \mathrm{cmbsf}$, after which it decreases to $23 \%$. Simultaneous with maximum Amaranthaceae values Hydrocotyle and Cyperaceae are most abundant, with maximum values of $14 \%$ for both. Following this, Poaceae (maximum of 7\%), Ambrosia and Asteraceae Tubuliflorae and - Iva-type (maximum of $4 \%$ ) are most abundant. This assemblage is typical for marshland. Of the trees Quercus is dominant, comprising up to $42 \%$ in the top of this zone. Other woody taxa found are Carya and Myrica cerifera ( $\sim 3 \%)$, and Ulmus, Fraxinus, Ostrya and Nyssa $(<1 \%)$, which are common in upland forests. With values up to $14 \%$ Pinus is the second most abundant tree in this zone. Taxodium pollen does not exceed 3\% of the assemblage. Mangrove taxa Rhizophora and Avicennia are present from 432.5 cmbsf up, albeit with values below $1 \%$.
Pollen zone TB-II. Pinus zone (340-39 cmbsf). A distinct shift to mainly Pinus at $\sim 340 \mathrm{cmbsf}$ marks the transition to the next zone, Pinus pollen comprising up to $83 \%$ of the total assemblage. Quercus shows a strong decrease as compared to the previous zone, but remains co-dominant (7-25\%). Other tree and shrub taxa that are found do not exceed 3\%. Liquidambar occurs for the first time in this zone, albeit with values around $1 \%$. The different herbaceous pollen types are practically absent in this zone $(<2 \%)$, with the exception of Amaranthaceae comprising up to $7 \%$.

The bulk of the herbaceous taxa are generally found in marsh environments, whereas the identified woody taxa (with exception of mangrove species and Taxodium) are most common in drier upland sites (Myers and Ewel, 1990; Willard et al., 2006). Shifts in the general abundance of the two groups are given in a summarizing diagram (Fig. 4), in which Pinus is given separately due to its expected remote origin.

The total pollen concentration appears to be fairly constant throughout the core $\left(\sim 4-10 \times 10^{4}\right.$ grains $\mathrm{g}^{-1}$ dry sediment $)$, with exception of two samples. At depth $432.5 \mathrm{cmbsf}$ concentrations are more than doubled, mainly caused by the high abundance of Amaranthaceae pollen in this sample. A very low concentration $\left(\sim 1 \times 10^{4}\right.$ grains $\mathrm{g}^{-1}$ dry sediment $)$ is found at $329 \mathrm{cmbsf}$.

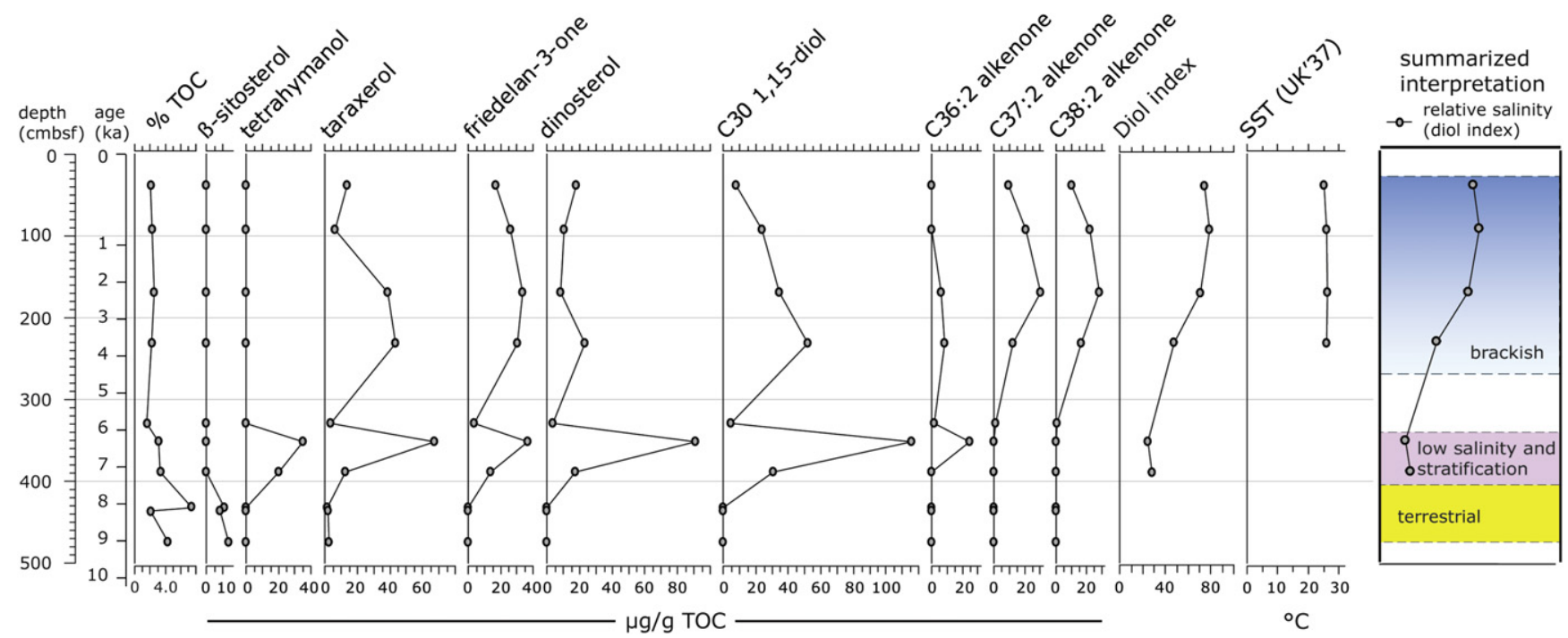

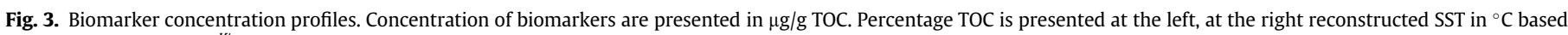
on paleothermometer $U_{37}^{K^{\prime}}$ and the Diol Index. Summarized interpretations are presented in the column at the far right. 


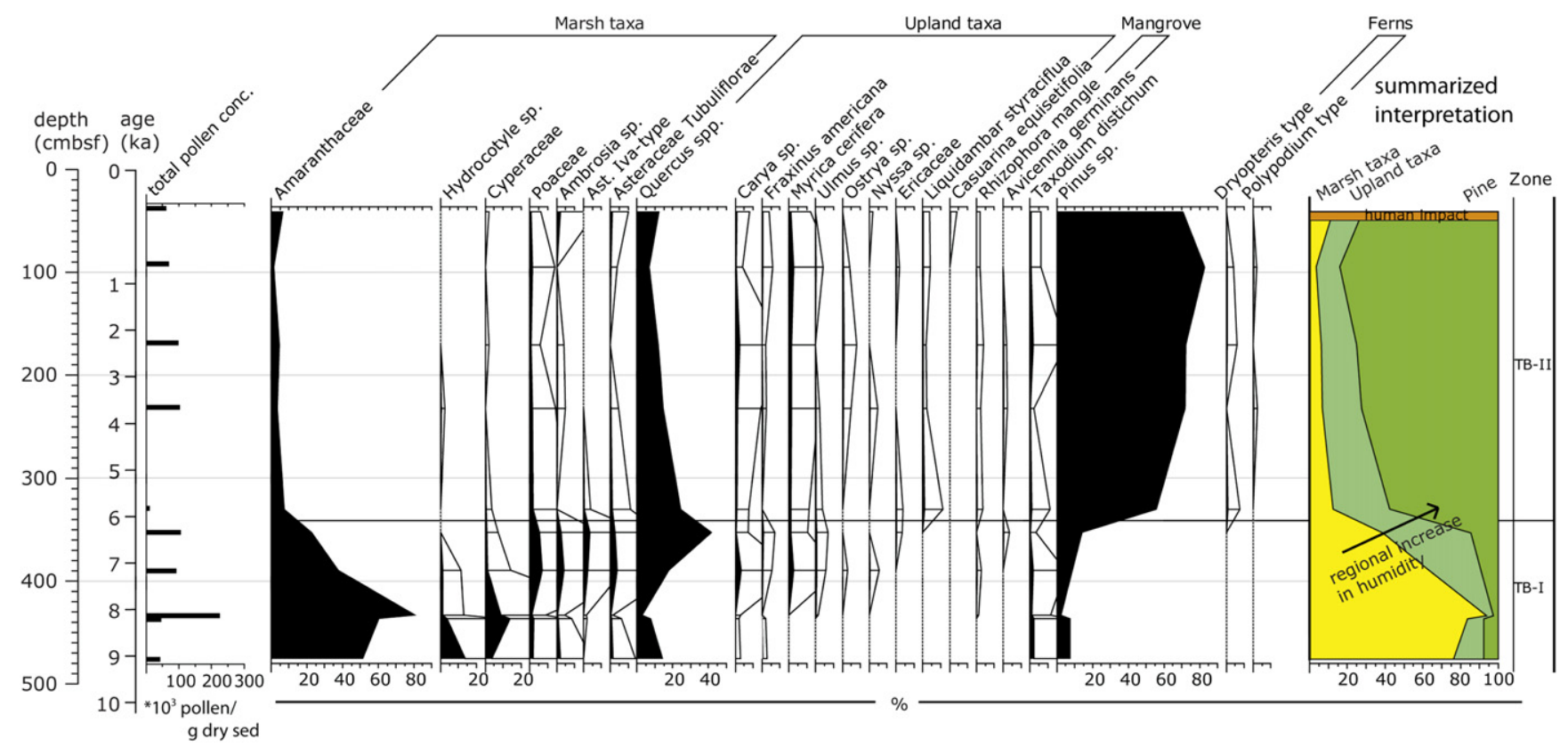

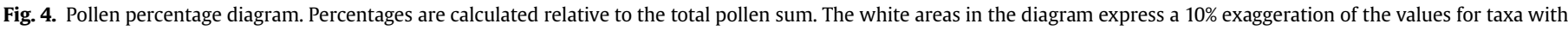

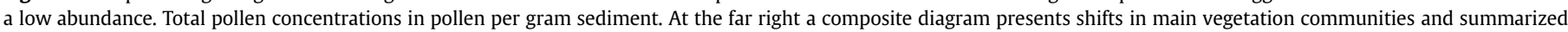
interpretations.

\subsection{Dinoflagellate cysts}

Relative abundances of the most represented dinocysts are shown in Fig. 5. From the bottom of the sediment core up to $389 \mathrm{cmbsf}$ no dinocysts are found. At $389 \mathrm{cmbsf}$ cysts are rare, and their number is too low (11 cysts) to be considered for the reconstructions. Between $352 \mathrm{cmbsf}$ and the core-top dinocysts are very abundant and their concentrations vary between $\sim 4$ and $\sim 25 \times 10^{4}$ grains $^{-1}$ dry sediment. The highest concentrations are found in the lower section, between 352 and $169 \mathrm{cmbsf}$, with exception of a minimum found at $329 \mathrm{cmbsf}\left(\sim 4 \times 10^{4}\right.$ grains $\mathrm{g}^{-1}$ dry sediment). Polysphaeridium zoharyi, Lingulodinium machaerophorum and Spiniferites spp. are the most represented species in the assemblages. P. zoharyi represents about $90 \%$ of the assemblages between 352 and $231 \mathrm{cmbsf}$. Above, the relative abundance drops and the minimum value is reached at $93 \mathrm{cmbsf}$. The upper part of the core shows again a slight increase. With the decrease of $P$. zoharyi between 231 and 169 cmbsf, relative abundances of L. machaerophorum and Spiniferites spp. increase. L. machaerophorum reaches its maximum of $37 \%$ at $169 \mathrm{cmbsf}$, and then slightly decreases in the upper part of the core. Spiniferites spp. increases up to values of about $40 \%$ in the upper part of the core. Other taxa found are rare and not persistently present in the core. Only Operculodinium spp. has been found throughout the core and shows a peak relative abundance of about $9 \%$ at $93 \mathrm{cmbsf}$.

\subsection{Diatoms}

Diatom preservation is generally moderate, and occasionally poor as valves are strongly corroded and sometimes only fragments are present. Diatoms are abundant from sample depth $389 \mathrm{cmbsf}$ up, with exception of sample depth $329 \mathrm{cmbsf}$ which was barren. Diatoms with highest abundances are presented in Fig. 6.

The diatom assemblage at $389 \mathrm{cmbsf}$ consists of more than $80 \%$ of an Amphora species for which further identification was not possible (Fig. 7). It resembles the marine-brackish species Amphora gacialis, a species of which the ecology and distribution is not well known. Following the Amphora-spike, the variety in diatoms becomes wider. Between 352 and 169 cmbsf, dominant species are Diploneis didyma, Hyalodiscus radiatus and Hyalodiscus scoticus, Planothidium delicatulum, Petroneis marina, Opephora spp. and Desikaneis gessneri. Between samples 169 and 39 cmbsf, Plagiogrammaceae, Amphicocconeis deculoides, Cyclotella litroalis, Actinophtychus senarius, Actinoptychus splendens and Paralia sulcata are dominant. Between 7 and $\sim 2 \mathrm{ka}$, polyhalobous diatoms comprise about $50 \%$ of the total diatom assemblage. From $\sim 2$ ka onwards, polyhalobous species increase relatively to mesohalobous species up to $80 \%$.

\section{Paleo-environmental reconstruction}

\subsection{Early-Holocene terrestrial environment}

Vegetation in the Early-Holocene (500-400 cmbsf, 10-7.5 ka) was dominated by a variety of herbaceous taxa commonly found in fresh and brackish water marshes. $\beta$-Sitosterol is the dominant biomarker in this part of the core. It is a non-specific phytosterol generally found in vascular plants (Scheuer, 1973; Nes, 1974; Killops and Killops, 2005), and since its concentration profile is comparable to abundance profiles of Hydrocotyle, Cyperaceae and Amaranthaceae, here it seems mainly derived from shrubs. The pinkish white to pale brown mud in this basal part of the record, dominated by nonmarine ostracodes and molluscs, was interpreted by Cronin et al. (2007) as lacustrine.

Considering these deposits and the found pollen assemblage the site can more specifically be indicated as a wet prairie or marlmarsh (Willard et al., 2001, 2006). The absence of diatoms in this section can possibly be the result of bad preservation of these fossils in this type of environment.

The transition in marsh taxa between 9.5 and $6.5 \mathrm{ka}$, from Hydrocotyle/Amaranthaceae/Cyperaceae dominance to Poaceae/ Asteraceae Tubuliflorae and Iva-type, which is a common shrub in coastal saline wetlands, is indicative for increasing salinities at the site. This trend is confirmed by the first occurrence of mangrove vegetation (Rhizophora mangle) around $7.5 \mathrm{ka}$, which suggests 


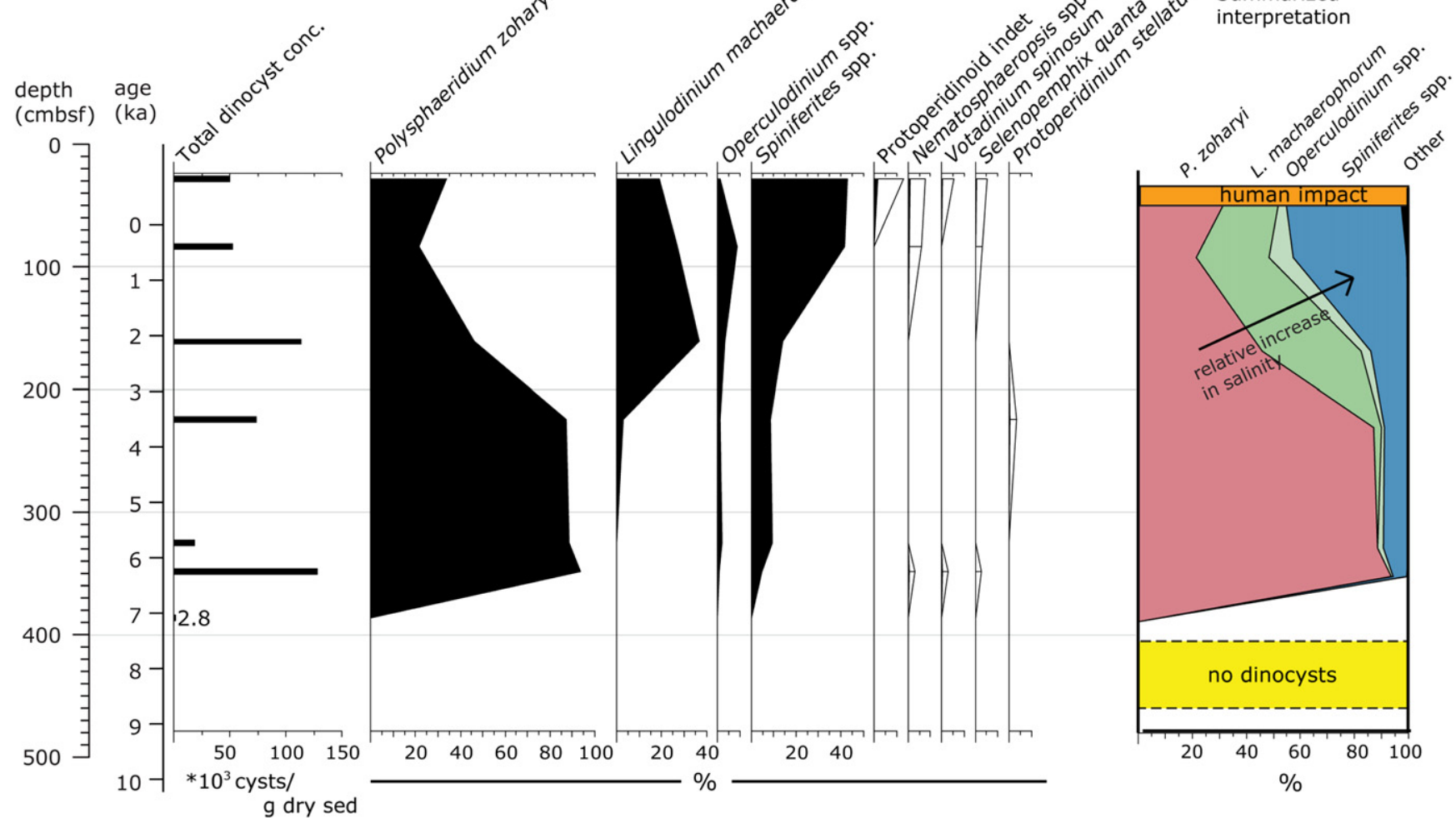

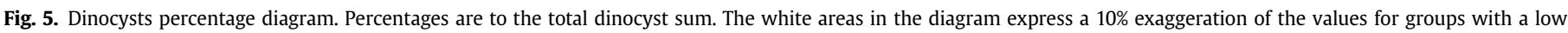

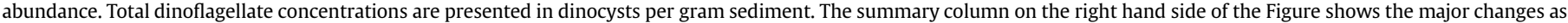
inferred from the dinocysts.

a change from an inland to a more coastal setting and further increasing salinities. Rhizophora pollen are small and they may be partly lost during sieving (Marret et al., 2001), this does not, however, necessarily affect the trend in the pollen curve (Versteegh et al., 2004). Absence of mangrove pollen before $~ 7.5 \mathrm{ka}$ might indicate that the low levels of taraxerol that were detected in this

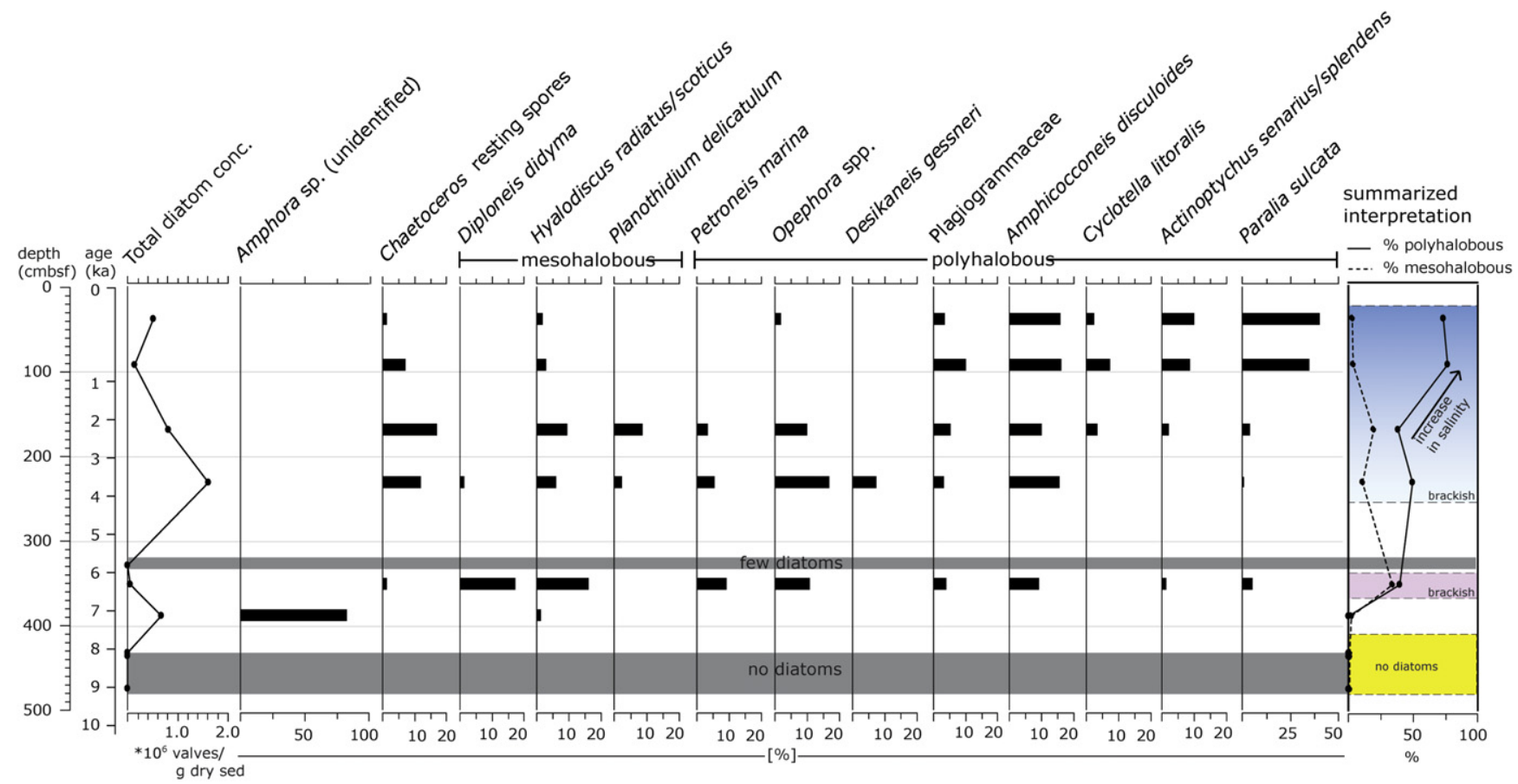

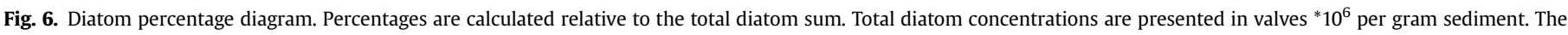
summary column on the right presents the ratio between polyhalobous and mesohalobous species and the interpretation. 

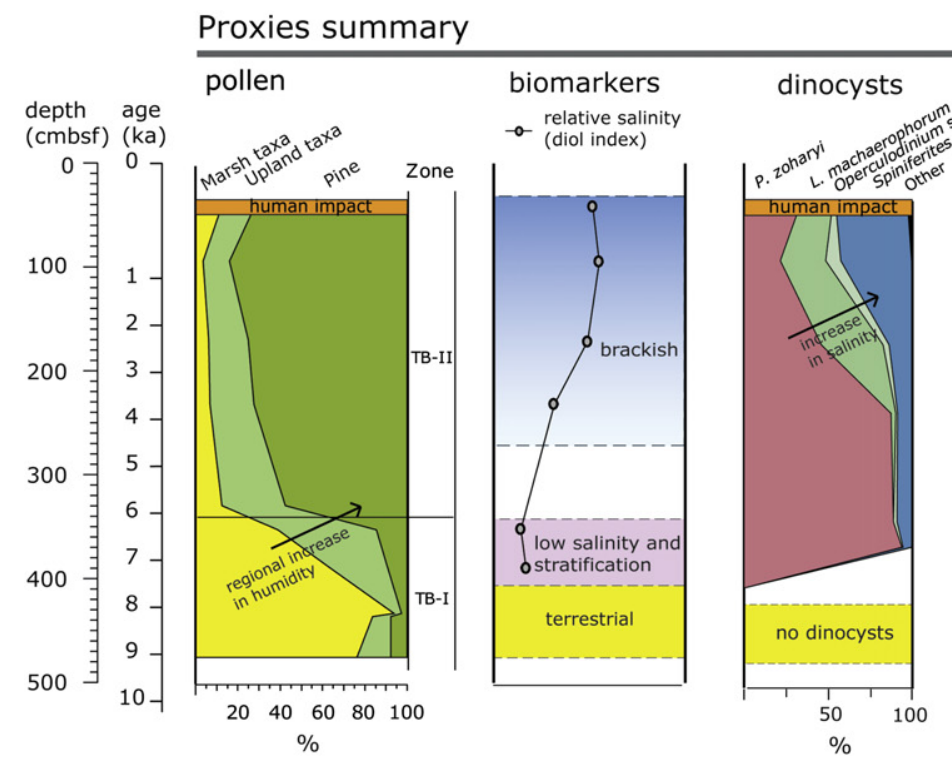

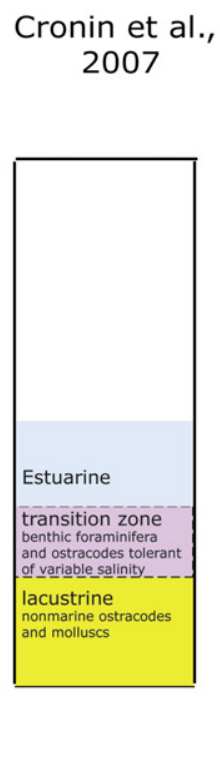

Combined

diatoms 2007 interpretation
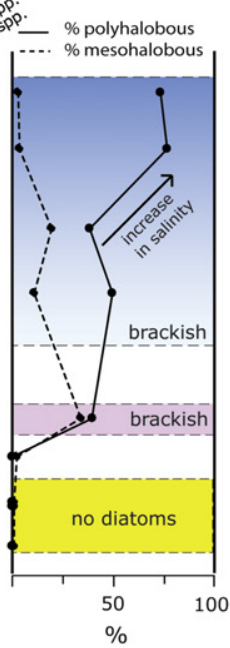

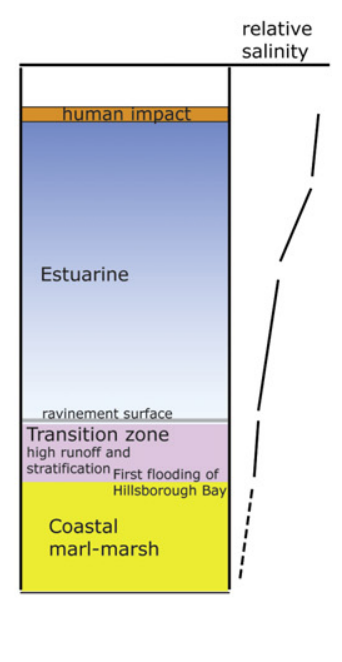

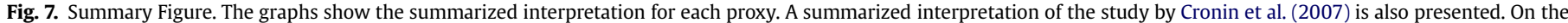
far right is the combined interpretation based on the multiple proxies and results by Cronin et al. (2007).

part of the core originate from vascular plants other than mangroves (Versteegh et al., 2004 and refs therein).

The variety of upland tree pollen found in this period originate from long-distance aeolian transport, as this site was probably part of an extensive marsh with little or no upland vegetation in the area. The dominance of Quercus between 9.5 and $6.5 \mathrm{ka}$ is in agreement with findings from inland lake records (Watts, 1969; $1971 ; 1975$; 1980; Watts and Hansen, 1994) and was interpreted as indicative of relative aridity in Florida (Watts and Hansen, 1994).

\subsection{Mid and Late Holocene marine transgression}

Hillsborough Bay initially flooded around $7.5 \mathrm{ka}$. Mid and Late Holocene deposits, (400 cmbsf - top, $7.5 \mathrm{ka}$ - present) contain terrestrial remains as well as aquatic remains like diatoms, dinocysts and biomarkers such as dinosterol and alkenones. The period between 7.5 and $6 \mathrm{ka}$ is characterized by relative high amounts of the biomarker tetrahymanol, which derives from ciliates and is indicative for water column stratification (Sinninghe Damsté et al., 1995). Between $\sim 7$ and $4 \mathrm{ka}$, up to $95 \%$ of the dinocyst assemblage is composed of $P$. zoharyi. This species is euryhaline, and can be found in warm and extremely stratified sea surface water environments (Marret and Zonneveld, 2003; Reichart et al., 2004; Sangiorgi et al., 2006). It can be particularly abundant in restricted marine environments like lagoons and bays and has been found abundantly in the estuarine surface sediments of Rookery Bay (Florida) (Cremer et al., 2007). Also $C_{30}$ and $C_{32}$ 1,15-diols are present in the sediments younger than $7.5 \mathrm{ka}$. These biomarkers most likely originate from eustigmatophytes, a group of eukaryotic algae (Volkman et al., 1992; Versteegh et al., 1997). The ratio between the two compounds, expressed in a Diol Index, is a function of salinity (Versteegh et al., 1997). Between 7.5 and 6 ka values for this index are about 25, typical for freshwater or restricted marine environments (Versteegh et al., 1997). Furthermore, longchain $C_{36}$ alkenones (position of double bonds at $\omega 15,20$ ) have their highest concentrations around $6.5 \mathrm{ka}$. These alkenones, which so far have an unknown origin, were earlier reported in sediments from the Black Sea (Xu et al., 2001) and Japan Sea (Fujine et al., 2006), where they were associated with low salinity surface water conditions. These results fit well with the idea that Tampa Bay consisted at that time of a series of restricted lagoons, related to karst depressions (Brooks et al., 2003; Locker et al., 2003), with limited water circulation.

Around $6 \mathrm{ka}$ there is a strong decrease in biomarker, pollen, dinocyst and diatom concentrations. The sample was taken from a distinct layer (sample depth $329 \mathrm{cmbsf}$ ), characterized by high levels of shell fragments and sand, in contrast to the mostly clayey sediments above and below this level (Cronin et al., 2007). The high amounts of shell fragments indicate a high-energy depositional environment and thus probably poor preservation or dilution of the micro-remains. Sediment cores from the shelf of west-central Florida show, in the same time period, a similar sedimentary pattern of low energy deposits, interrupted by a sharp erosional contact and followed by a coarse, but fining upward, shell layer. Brooks et al. (2003) interpreted the erosional contact as a ravinement surface and the shell layer as the initial shoreface deposition. Besides transgression, also storms will have affected sedimentation either by erosion due to storm surges or by increased runoff and consequent soil erosion. In Waccasassa Bay, north of Tampa Bay, storm driven surges were found to be an important mechanism for marsh surface accretion during the Holocene (Goodbred et al., 1998).

Increasing concentrations of friedelanone and disappearance of $\beta$-sitosterol around 7.5 ka suggest a change in vegetation cover and coincides with the terrestrial-marine transition already suggested by Cronin et al. (2007). Friedelanone, like $\beta$-sitosterol, originates from vascular plants (Scheuer, 1973; Nes, 1974; Killops and Killops, 2005). Possibly, $\beta$-sitosterol represents local herbaceous vegetation, which disappears when the environment becomes brackish. Marsh vegetation disappears almost completely from the pollen record simultaneous with the expansion of Pinus, between 6 and $5.5 \mathrm{ka}$. First occurrences of pollen of a number of plant and tree species like Liquidambar and ferns in this interval also indicate that the site became part of a more open area with a regional long-distance pollen input, rather than indicating changes in the local vegetation composition. Also friedelanone probably represents a more combined regional signal from the hinterland. The bisaccate Pinus pollen grains facilitate long-distance dispersal both by fluvial and aeolian transport, which might result in an over representation of this species. High levels of Pinus have been recovered for this period 
in sites throughout the peninsula (Watts, 1969, 1971, 1975, 1980, Watts and Hansen, 1994) and the expansion of pine forest is thought to be the result of warmer winters and increased precipitation (Watts and Hansen, 1994; Grimm et al., 2006). These changes are however not clearly reflected in any of the other proxies where it is possibly overwhelmed by the response to sea-level rise.

Long-chain $\mathrm{C}_{37}-\mathrm{C}_{38}$ alkenones present from $\sim 4 \mathrm{ka}$ and onwards, are biosynthesized exclusively by certain haptophyte algae, like Emilinia huxleyi and Gephyrocapsa oceanica. Reconstructed SST, based on the global core-top calibration of Müller et al (1998) correspond well with current Tampa Bay spring temperatures of $24-26^{\circ} \mathrm{C}$ (nodc.noaa.gov), the period during which major groups of phytoplankton bloom in Florida bays and on the Florida shelf (Gilbes et al., 1996; Dixon et al., 2009).

A transition to higher salinities towards the late Holocene is evident from a sharp increase in L. machaerophorum from $3 \mathrm{ka}$, followed by increases in Spiniferites spp. and polyhalobous diatoms. Also the Diol Index increases to about 80, which is typical for open marine conditions (Versteegh et al., 1997). L. machaerophorum has been recorded from brackish to fully marine environments, with salinity ranging between 16.9 and 36.7, while the genus Spiniferites is usually found in waters with salinity higher than 22 (Marret and Zonneveld, 2003). Polyhalobous diatoms have an affinity for salinities higher than 30 , while mesohalobous diatoms thrive at salinities between 0.2 and 30 . Combined proxies thus indicate progressing Holocene sea-level rise. A continuous marine submergence, with decelerating rates after $5 \mathrm{ka}$, was also proposed by Scholl et al. (1969).

The lowest occurrence of Casuarina between depth 93-39 cmbsf indicates a shift towards higher sedimentation rates in the upper part of the core. This could partly be the result of lower compaction in the upper part of the sedimentary layer. However, the increase in sedimentation rate seems rather abrupt. Brooks (in press) reported a 10-fold increase in sedimentation rates in Tampa Bay over the past century, probably as a result of increased human activities in the areas surrounding Tampa Bay. The anthropogenic impact seems however, to have had little effect on the different proxies. A small decrease in pine might indicate a change in land use and in the marine realm a slight increase in some heterotrophic dinocysts (Protoperidinioids, Votadinium spinosum, Selenopemphix quanta) could indicate a higher nutrient input and higher productivity (Marret and Zonneveld, 2003).

\section{Conclusions}

Combined biomarker, pollen, dinocyst and diatom records clearly show the environmental evolution of Tampa Bay under the influence of rising Holocene sea-level. Around 7.5 ka Tampa Bay is flooded and the pollen signal becomes representative of a larger catchment area. Between $7.5 \mathrm{ka}$ and $\sim 5 \mathrm{ka}$, the bay is characterized by low salinity surface waters and water column stratification. In this period the area is certainly more sensitive to storm and hurricane activity and the associated storm surges likely resulted in sedimentary hiatuses and/or storm deposits. Aquatic and marine proxies indicate increasing salinities from $7.5 \mathrm{ka}$ to the present, which is likely the consequence of sea-level rise following the last deglaciation. Around $6.5 \mathrm{ka}$, a change in vegetation from Quercus to Pinus indicate a regional change towards more humid conditions. Reconstructed SST for the past 4 kyrs are between 25 and $26^{\circ} \mathrm{C}$ and indicate stable temperatures during this period. A sharp increase in sedimentation rate in the top $\sim 50 \mathrm{~cm}$ of the core is ascribed to human impact and coherent with other studies in the surroundings of Tampa Bay.

This environmental interpretation is in agreement with Cronin et al. (2007) who recognized a transition from lacustrine to estuarine conditions around $7.5 \mathrm{ka}$ in the same sediment core. While the previous study established the presence of sea-level rise at this site, this study provides a more detailed interpretation of the environment, like the transition from fresh to brackish/marine conditions. Proxies are in agreement with each other, which makes the environmental interpretation reliable. At the applied resolution, the marine signal is determined by the rising sea-level. When higher resolution will be achieved; changes in SST, humidity and salinity can provide information on past changes in the climate system and the effects in this area.

\section{Acknowledgements}

A Utrecht University HIPO grant to Friederike Wagner-Cremer, Stefan Dekker and Gert-Jan Reichart provided the funding for this research. Gijs Nobbe and Natasja Welters are acknowledged for analytical assistance. Thomas Cronin is thanked for providing C-14 dates for this core. Samples were kindly provided by the USGS.

\section{References}

Alexander, T.J., Crook, A.G., 1974. Recent Vegetational Changes in Southern Florida. In: Gleason, P.J. (Ed.), Environments of South Florida: Present and Past. The Miami Geological Society, Miami, pp. 61-72.

Battarbee, R.W., 1973. A new method for estimation of absolute microfossil numbers, with reference especially to diatoms. Limnology and Oceanography $18,647-653$

Blum, M.D., Misner, T.J., Collins, E.S., Scott, D.B., Morton, R.A., Aslan, A., 2001. Middle Holocene sea-level rise and highstand at $12 \mathrm{~m}$, Central Texas coast. Journal of Sedimentary Research 71 (4), 581-588.

Brooks, G.R. Florida Gulf Coast Estuaries: Tampa Bay and Charlotte Harbor. Gulf of Mexico, Origin, Waters, and Marine Life. A\&M Press: College Station, Texas; in press.

Brooks, G.R., Doyle, L.J., Suthard, B.C., Locker, S.D., Hine, A.C., 2003. Facies architecture of the mixed carbonate/siliciclastic inner continental shelf of westcentral Florida: implications for Holocene barrier development. Marine Geology 200, 325-349.

Cremer, H., Sangiorgi, F., Wagner-Cremer, F., McGee, V., Lotter, A.F., Visscher, H., 2007. Diatoms (Bacillariophyceae) and dinoflagellate cysts (Dinophyceae) from Rookery Bay, Florida, U.S.A. Carribean Journal of Science 43, 23-58.

Cronin, T., Edgar, N.T., Brooks, G., Hastings, D., Larson, R., Hine, A., Locker, S., Suthard, B., Flower, B., Hollander, D., Wehmiller, J., Willard, D., Smith, S., 2007. Sea level rise in Tampa Bay. Eos 88, 10 .

Dixon, L.K., Vargo, G.A., Johansson, J.O.R., Montgomery, R.T., Neely, M.B., 2009. Trends and explanatory variables for the major phytoplankton groups of two southwestern Florida estuaries, U.S.A. Journal of Sea Research 61 (1-2), 95-102.

Donders, T.H., Gorissen, P.M., Sangiorgi, F., Cremer, H., Wagner-Cremer, F., McGee, V., 2008. Three-hundred-year hydrological changes in a subtropical estuary, Rookery Bay (Florida): human impact versus natural variability. Geochemistry Geophysics and Geosystems 9.

Donders, T.H., Wagner, F., Dilcher, D.L., Visscher, H., 2005. Mid- to late-Holocene El Niño-southern oscillation dynamics reflected in the subtropical terrestrial realm. PNAS 102 (31), 10904-10908.

Fensome, R.A., Williams, G.L., 2004. The Lentin and Williams Index of Fossil Dinoflagellates. In: Contributions Series, vol. 42. AASP Foundation. 2004 Edition909.

Fujine, K., Yamamoto, M., Tada, R., Kido, Y., 2006. A salinity-related occurrence of a novel alkenone and alkenoate in late pleistocene sediments from the Japan Sea. Organic Geochemistry 37, 1074-1084.

Gilbes, F., Tomas, C., Walsh, J.J., Müller-Karger, F.E., 1996. An episodic chlorophyll plume on the west Florida shelf. Continental Shelf Research 16 (9), 1201-1224.

Goodbred, S.L.J., Wright, E.E., Hine, A.C., 1998. Sea-Level change and storm-surge deposition in a Late Holocene Florida salt marsh. Journal of Sedimentary Research 68 (2), 240-252.

Grimm, E.C., Watts, W.A., Jacobson Jr., G.L., Hansen, B.C.S., Almquist, H.R., Dieffenbacher-Krall, A.C., 2006. Evidence for warm wet Heinrich events in Florida. Quaternary Science Reviews 25 (17-18), 2197-2211.

Hustedt, F., 1930-1966. Die Kieselalgen Deutschlands, Österreichs und der Schweiz unter Berücksichtigung der übrigen Länder Europas sowie der angrenzenden Meeresgebiete. Dr. L. Rabenhorts Kryptogamen-Flora, Band VII, Die Kieselalgen Koenigstein, Otto Koeltz Science Publishers.

Hustedt, F., 1955. Marine littoral diatoms of Beaufort, North Carolina. Duke University Marine Station Bulletin 6, 1-67.

Killops, S.D., Killops, V.J., 2005. Introduction to Organic Geochemistry. Blackwell Publishing, Oxford.

Laws, R.A., 1988. Diatoms (Bacillariophyceae) from surface sediments in the San Francisco bay estuary. Proceedings of the California Academy of Sciences 45, 133-154. 
Locker, S.D., Hine, A.C., Brooks, G.R., 2003. Regional stratigraphic framework linking continental shelf and coastal sedimentary deposits of west-central Florida. Marine Geology 200 (1-4), 351-378.

Marret, F., Scourse, J.D., Versteegh, G.J.M., Jansen, F.J.H., Schneider, R., 2001. Integrated marine and terrestrial evidence for abrupt Congo river palaeodischarge fluctuations during the last deglaciation. Journal of Quaternary Science 16 (8), 761-766.

Marret, F., Zonneveld, K.F., 2003. Atlas of modern organic-walled dinoflagellates cyst distribution. Review of Palaeobotany and Palynology 125, 1-200.

Müller, P.J., Kirst, G., Ruhland, G., von Storch, I., Rosell-Melé, A., 1998. Calibration of the alkenone paleotemperature index U37K' based on core-tops from the eastern South Atlantic and the global ocean $\left(60^{\circ} \mathrm{N}-60^{\circ} \mathrm{S}\right)$. Geochimica et Cosmochimica Acta 62 (10), 1757-1772.

Myers, R.L., Ewel, J.J. (Eds.), 1990. Ecosystems of Florida. University of Central Florida Press, Orlando.

Nes, W., 1974. Role of sterols in membranes. Lipids 9 (8), 596-612.

Prahl, F.G., Wakeham, S.G., 1987. Calibration of unsaturation patterns in long-chain ketone compositions for palaeotemperature assessment. Nature 330 (6146), 367-369.

Reichart, G.-J., Brinkhuis, H., Huiskamp, F., Zachariasse, W.J., 2004. Hyperstratification following glacial overturning events in the northern Arabian Sea. Paleoceanography 19.

Rochon, A., de Vernal, A., Turon, J.-L., Matthiessen, J., Head, M., 1999. Distribution of Dinoflagellate Cysts in Surface Sediments From the North Atlantic Ocean and Adjacent Basins, and Quantitative Reconstruction of Sea Surface-Water Parameters. In: Contribution Series, vol. 35. American Association of Stratigraphic Palynologists. 64.

Sachs, J.P., Anderson, R.F., 2005. Increased productivity in the subantarctic ocean during Heinrich events. Nature 434 (7037), 1118-1121.

Sangiorgi, F., Dinelli, E., Maffioli, P., Principato, S., Capotondi, L., Giunta, S., Morigi, C., Emeis, K.C., Negri, A., Corselli, C., 2006. Geochemical and micropaleontological characterisation of a Mediterranean sapropel S5: a case study from core BAN89GC09 (south of Crete). Palaeogeography, Palaeoclimatology, Palaeoecology 235, 192-207.

Scheuer, P.J., 1973. Chemistry of Marine Natural Products. Academic Press, New York.

Scholl, D.W., Craighead Sr., F.C., Stuiver, M., 1969. Florida submergence curve revised: its relation to coastal sedimentation rates. Science 163 (3867), 562-564.

Simonsen, R., 1962. Untersuchungen zur Systematik und Ökologie der Bodendiatomeen der westlichen Ostsee. International Revue der gesamten Hydrobiologie, Systematische Beihefte 1,1-144.

Sinninghe Damsté, J.S., Kenig, F., Koopmans, M.P., Koster, J., Schouten, S., Hayes, J.M., De Leeuw, J.W., 1995. Evidence for gammacerane as an indicator of water column stratification. Geochimica et Cosmochimica Acta 59 (9), 1895-1900.

Törnqvist, T.E., González, J.L., Newsom, L.A., Borg, K.v. d., Jong, A.F.M.d., Kurnik, C.W., 2004. Deciphering Holocene sea-level history on the U.S. Gulf Coast: a highresolution record from the Mississippi Delta. GSA Bulletin 116 (7-8), 1026-1039.
Tyler, D., Zawada, D.G., Nayegandhi, A., Brock, J.C., Crane, M.P., Yates, K.K. \& Smith K.E.L., 2007. Topobathymetric Data for Tampa Bay, Florida: U.S. Geological Survey Open-File Report 2007-1051 (revised).

Van der Meer, M., Sangiorgi, F., Baas, M., Brinkhuis, H., Sinninghe Damste, J.S. Schouten, S., 2008. Molecular isotopic and dinoflagellate evidence for Late Holocene freshening of the Black Sea. Earth and Planetary Science Letters 267, 426-434.

Versteegh, G.J.M., Bosch, H.J., De Leeuw, J.W., 1997. Potential palaeoenvironmental information of C24 to C36 mid-chain diols, keto-ols and mid-chain hydroxy fatty acids; a critical review. Organic Geochemistry 27 (1-2), 1-13.

Versteegh, G.J.M., Schefuß, E., Dupont, L., Marret, F., Sinninghe Damsté, J.S. Jansen, J.H.F., 2004. Taraxerol and Rhizophora pollen as proxies for tracking past mangrove ecosystems. Geochimica et Cosmochimica Acta 68 (3), 411-422.

Volkman, J.K., Barrett, S.M., Dunstan, G.A., Jeffrey, S.W., 1992. C30-C32 alkyl diols and unsaturated alcohols in microalgae of the class Eustigmatophyceae. Organic Geochemistry 18 (1), 131-138.

Watts, W.A., 1969. A pollen diagram from Mud Lake, Marion County, North Central Florida. Geological Society of America Bulletin 90, 631-642.

Watts, W.A., 1971. Postglacial and Interglacial vegetation history of southern Georgia and central Florida. Ecology 52, 676-690.

Watts, W.A., 1975. A late Quaternary reocord of vegetation from Lake Annie, southcentral Florida. Geology 3, 344-346.

Watts, W.A., 1980. The late Quaternary vegetation of south-eastern United States. Annual Review of Ecology and Systematics 11, 387-409.

Watts, W.A., Hansen, B.C.S., 1994. Pre-Holocene and Holocene pollen records of vegetation history from the Florida peninsula and their climatic implications. Palaeogeography, Palaeoclimatology, Palaeoecology 109, 163-176.

Willard, D., Bernhardt, C.E., Holmes, C.W., Landacre, B., Marot, M., 2006. Response of Everglades tree islands to environmental change. Ecological Monographs 76 (4), 565-583.

Willard, D.A., Bernhardt, C.E., Brooks, G.R., Cronin, T.M., Edgar, T., Larson, R., 2007 Deglacial climate variability in central Florida, USA. Palaeogeography, Palaeoclimatology, Palaeoecology 251 (3-4), 366-382.

Willard, D.A., Bernhardt, C.E., Weimer, L., Cooper, S.R., Gamez, D., Jensen, J., 2004. Atlas of pollen and spores of the Florida Everglades. Palynology 28, 175-227.

Willard, D.A., Holmes, C.W., Weimer, L.M., 2001. The Florida everglades ecosystem: climatic and anthropogenic impacts over the last two millennia. Bulletins of American Paleontology 361, 41-55.

Witkowski, A., Lange-Bertalor, H., Metzeltin, D., 2000. Diatom flora of marine coasts I. Iconographia Diatomologica 7, 1-925.

Wood, G.D., Gabriel, A.M., Lawson, J.C., 1996. Palynological techniques -processing and microscopy (Chapter 3). In: Jansonius, J., M., D.C. (Eds.), Palynology: Principles and Applications. American Association of Stratigraphic Palynologists Foundation, pp. 29-50.

Xu, L., Reddy, C.M., Farrington, J.W., Frysinger, G.S., Gaines, R.B., Johnson, C.G., Nelson, R.K., Eglinton, T.I., 2001. Identification of a novel alkenone in Black Sea sediments. Organic Geochemistry 32 (5), 633-645. 